\title{
Antimicrobial activity of silver nanoparticles in treating dental caries
}

\section{Atividade antimicrobiana de nanopartículas de prata no tratamento da cárie dentária}

\author{
Andréa Gadelha Ribeiro Targino* \\ Miguel Angel Pelagio Flores* \\ Valdeci Elias Santos Junior ${ }^{* * *}$ \\ Hilzeth de Luna Freire Pessoa ${ }^{* * * *}$ \\ André Galembeck ${ }^{* * * * *}$ \\ Aronita Rosenblatt ${ }^{* * *+* *+2}$
}

\begin{abstract}
Objective: to clarify the benefits related to the use of silver nanoparticles (AgNPs) in the prevention of dental caries in children, we compared the antibacterial properties of silver nanoparticles, chlorhexidine, and silver diamine fluoride (SDF) to Streptococcus mutans. Materials and method: to analyze the minimum inhibitory concentration (MIC) we used the spectrophotometric microdilution method (SMM), and turbidity. We also verified the minimum bactericidal concentration (MBC) of the target products. Analysis of variance (ANOVA) was used to compare MIC and MBC among the groups studied. Results: regarding antimicrobial proprieties, the tested substances showed effective bacteriostatic and bactericide activity. The silver nanoparticles had the lowest value of MIC against reference strains (ATCC $25175)(p<0.05)$. In clinical strains, the MIC value of silver nanoparticles was comparable to that of chlorhexidine $(p>0.05)$, and lower than SDF $(p<0.05)$. Conclusion: silver nanoparticles proved to have antimicrobial activity against $S$. mutans, therefore, they may be an effective agent in the prevention of dental caries.
\end{abstract}

Keywords: Dental caries. Microbiology. Streptococcus mutans.

\section{Introduction}

Dental caries in children is still one of the world's major public health problems since it has a strong impact on individuals and communities in terms of pain and suffering, impairment of function, and reduced quality of life. The current pattern of oral disease reflects distinct risk profiles across countries regarding living conditions, behavioral and environmental factors, oral health systems, and implementation of policies to prevent oral disease ${ }^{1}$. Streptococcus mutans ( $S$. mutans) has been implicated as the main pathogen involved in the development of dental caries, which is the reason why many Dentistry studies have been focused on isolating this microorganism to determine its pathogenicity ${ }^{2,3}$.

Some studies indicate that the antibacterial mechanism of the silver nanoparticles (AgNPs) relays on their ability to penetrate the bacterial cell wall, causing direct and indirect lipidic peroxidation, which damages the cell membrane, disrupts the DNA replication, and repairs and inhibits the respiratory protein $^{4,5}$.

DDS, MSc. Ph.D. - Department of Pediatric Dentistry, School of Dentistry, University of Pernambuco, Brazil.

MSc. - Department of Chemical Sciences, Federal University of Pernambuco, Brazil.

DDS, MSc. Ph.D. Post- DOC - Department of Pediatric Dentistry, School of Dentistry, University of Pernambuco, Brazil.

MSc, Ph.D. - Department of Biological Science, School of Biological Science, Federal University of Paraíba, Brazil.

MSc. Ph.D. - Department of Chemical Sciences, Federal University of Pernambuco, Brazil.

DDS. MSc. Ph.D. Professor of Pediatric Dentistry. School of Dentistry, University of Pernambuco, Brazil. 
The size reduction of the AgNPs involves an increase in the contact surface, which is an important condition for the antimicrobial effects of silver and could prevent black staining in teeth, as occurs after application of silver diamine fluoride (SDF). Thus, a powerful antimicrobial activity without esthetic modifications and low production cost may be achieved with the use of silver nanoparticles for the treatment of dental caries ${ }^{6}$.

This study aims to compare the bactericidal and bacteriostatic effects of quasi-spherical AgNPs with an average size of $35 \pm 10 \mathrm{~nm}$ to chlorhexidine and $\mathrm{SDF}$, considering that the latest two solutions are currently the medicines of choice for early caries prevention. The authors hypostatized that a powerful antimicrobial agent containing silver nanoparticles could be designed to be effective in arresting and preventing tooth decay with the advantage of not staining teeth.

\section{Materials and method}

\section{Design}

This was an experimental in vitro study performed at the Federal University of Paraiba (UFPB) and the Northeast Technological Center (Centro de Tecnologia do Nordeste - CETENE), in collaboration with CETENE were the University of Pernambuco (UPE), the Federal University of Pernambuco (UFPE), and UFPB.

\section{Strains and medium}

The following microbial strains were used: $S$. mutans ATCC 25175, and clinical strains. They were collected at the Dentistry clinic of the Federal University of Paraiba/UFPB, taken to the laboratory in a sterile recipient kept on ice, and immediately processed. These strains were pre-cultivated in brain hearth infusion (BHI) broth (Himedia).

\section{Materials}

A $39.51 \mu \mathrm{g} / \mathrm{mL}$ solution of silver nanoparticles (AgNPs) with particle size of $35 \pm 10 \mathrm{~nm}$ composed the experimental material; $0.12 \%$ Chlorhexidine (Unica) (starting concentration of ATCC strains was $24 \mathrm{\mu g} /$ $\mathrm{mL}$, and $1200 \mathrm{\mu g} / \mathrm{mL}$ of clinical strains), and $30 \%$ silver diamine fluoride (SDF) (Biodinamica) (starting concentration $200 \mu \mathrm{g} / \mathrm{mL}$ ) were used as controls.

\section{Manufacturing of silver nanoparticles}

\section{Experimental materials}

Silver nitrate $\left(\mathrm{AgNO}_{3}, \geq 99 \%\right)$, L-ascorbic acid $\left(\mathrm{C}_{6} \mathrm{H}_{8} \mathrm{O}_{6}, \geq 99 \%\right)$, trisodium citrate $\left(\mathrm{Na}_{3} \mathrm{C}_{6} \mathrm{H}_{5} \mathrm{O}_{7}\right.$, $\geq 99 \%$ ) were the analytical grade, and were used without further purification. Deionized water (18 $\mathrm{M} \Omega$ ) was used in all experiments.

\section{Preparation of silver nanoparticles (AgNPs)}

The synthesis of silver nanoparticles was carried out by using ascorbic acid as a reducing agent, and sodium citrate as a stabilizing agent at $30{ }^{\circ} \mathrm{C}$. Typically, $1 \mathrm{~mL}$ of L-ascorbic acid aqueous solution $\left(10.8 \times 10^{-3} \mathrm{molL}^{-1}\right)$ was dropped under magnetic stirring into $29.0 \mathrm{~mL}$ of an aqueous solution containing $\mathrm{AgNO}_{3}\left(3.8 \times 10^{-4} \mathrm{molL}^{-1}\right)$, and trisodium citrate $\left(19.0 \times 10^{-4} \mathrm{molL}^{-1}\right)$. The sample changed from colorless to green within $30 \mathrm{~min}$. No further changes occurred, as detected by an absorption spectroscopy.

\section{Antimicrobial test}

The minimum inhibitory concentrations (MICs) for the experimental solutions were assessed using a spectrophotometric microdilution method (SMM) and turbidity. For each strain we used a 96-well ELISA plate, and solutions were colored with resazurin (Sigma). To generate a checkboard, rows 1 and 2 were filled with control solutions (chlorhexidine and SDF), and from 3 on, the experimental solutions. Row 8 was used to insure the viability of bacteria strains, sterility of experimental solutions, and sterility of the medium. The solutions were subjected to a series of dilutions, and inserted in columns 1 through 12 . The wells from rows 1 and 2 were filled with $140 \mu \mathrm{L}$ BHI, $50 \mu \mathrm{L}$ of control solution and $10 \mu \mathrm{L}$ of exponentially growing bacterial culture (about $10^{8}$ colony-forming units/ $\mathrm{mL}$ ). The wells of row 3 were filled with $100 \mu \mathrm{L}$ BHI, $100 \mu \mathrm{L}$ of experimental solutions, and $10 \mu \mathrm{L}$ of exponentially growing culture. The plate was incubated at $37{ }^{\circ} \mathrm{C}$ for 18 hours, and the absorbance of each well was determined using an automatic ELISA tray reader (READWELL PLATE VERSION RBNK 3.309) adjusted at $630 \mathrm{~nm}$, before and after incubation. Then all wells were filled with the oxidation-reduction indicator resazurin (Sigma) to assure the true viability of antimicrobial activity, since the AgNPs preparation is highly light scattering by nature (more turbid than stationary-phase bacteria), and therefore, traditional turbidimetry would not be effective.

The MIC value was expressed as the lowest concentration inhibiting the bacterial growth. Minimum bactericidal concentrations (MBCs) were determined when aliquots from the MIC wells did not present visible bacterial growth on plates with Brain Heart Infusion Agar, and incubated at $37^{\circ} \mathrm{C}$ for $24 \mathrm{~h}$. The MBC is defined as the lowest concentration of antibacterial agent that kills microorganism $^{8}$. All tests were performed in triplicate. 


\section{Statistical analysis}

Measures of central tendency and dispersion were calculated for each of the variables studied. Analysis of variance (ANOVA) was used to compare MIC and MBC among groups studied. A value of $p$ $<0.05$ was considered statistically significant. The T-test was used for analysis of differences between clinical and ATCC strains. The Dunnett Test was used for analysis of differences between the experimental group and the control group (chlorhexidine and SDF). We used GraphPad Prism 5.0 software to analyze data.

\section{Results}

Figure 1 presents typical images from transmission electron microscopy (TEM) of the resulting silver nanoparticles. The average particle size is $35 \pm$ $10 \mathrm{~nm}$, mostly with spherical morphology.

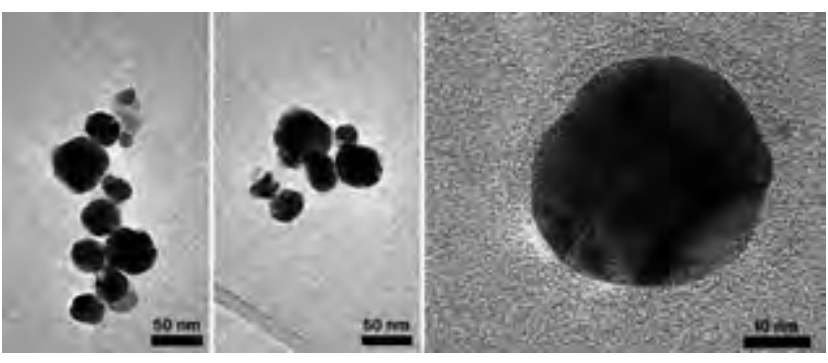

Figure 1 - Transmission electron microscopy (TEM) of silver nanoparticles

The tested substances showed bactericidal activity. The silver nanoparticles showed the lowest value in the reference strains MIC $0.20 \pm 0.08$ and MBC $0.32 \mu \mathrm{g} / \mathrm{mL}$ to ATCC, and MIC19.76 \pm 0.123 and MBC $39.52 \mu \mathrm{g} / \mathrm{mL}$ to clinical strains ( $<<0.05$ ). In the clinical strains the silver nanoparticles value was comparable to that of chlorhexidine ( $p>0.05)$, and lower than SDF $(\mathrm{p}<0.05)$ (Table 1).

Table 1 - Minimum inhibitory concentration of AgNPs, and control solutions against clinical and reference stocks of S. mutans

\begin{tabular}{|c|c|c|c|c|}
\hline \multirow[b]{2}{*}{ Sample } & \multicolumn{2}{|c|}{$\begin{array}{c}\text { MIC } \\
\text { Average } \pm \mathrm{SD}(\mu \mathrm{g} / \mathrm{mL})\end{array}$} & \multicolumn{2}{|c|}{$\begin{array}{c}\mathrm{MBC} \\
(\mu \mathrm{g} / \mathrm{mL})\end{array}$} \\
\hline & Clinical strains & Reference strains & Clinical strains & Reference strains \\
\hline AgNPs & $19.76 \pm 0.123$ & $0.20 \pm 0.08$ & 39.52 & 0.32 \\
\hline Chlorhexidine & $20.50 \pm 3.03^{(1)}$ & $3.3 \pm 0.5^{(2)}$ & $75^{(1)}$ & $6^{(2)}$ \\
\hline SDF & $560 \pm 69.7^{(1)}$ & $30 \pm 8.6^{(1)}$ & $1000^{(1)}$ & $50^{(1)}$ \\
\hline
\end{tabular}

(1) statistically significant

(2) No statistically significant

\section{Discussion}

In Dentistry, AgNPs have been studied to control oral biofilm formation in dental restorative materials ${ }^{9-11}$, and in dental implants ${ }^{12}$. However, for caries prevention, there is still a lack of evidence-based knowledge to indicate its use as a nonsurgical management of dental caries.

In the present study we tested antimicrobial activity of AgNPs with approximately $35 \pm 10 \mathrm{~nm}$, and compared them to chlorhexidine, which reduced S. mutans in saliva, and to SDF, which prevented and arrested caries in first permanent molars and primary teeth ${ }^{13}$. Our results highlight the great power of AgNPs as an anticaries agent against $S$. mutans ATCC and clinical strains, because of its small MIC values as compared to chlorhexidine and SDF, being 28.34-fold lower than that of SDF.

The size of the spherical nanoparticles produced for this invention is in the range of $35 \pm 10 \mathrm{~nm}$, proving that the antibacterial activity of silver nanoparticles against $S$. mutans increases as particle size decreases, which meets the findings by Espinosa-Cristobal et al. $(2009)^{14}$, Morones et al. $(2005)^{15}$, and Baker et al. $(2005)^{16}$. Studies have indicated that the silver in SDF interacts with sulfhydryl groups of proteins, and with DNA, altering hydrogen bonding and inhibiting respiratory processes, DNA unwinding, cell-wall synthesis, and cell divi$\operatorname{sion}^{13}$. The silver contained in the SDF has a much smaller contact surface than the silver nanoparticles, which explains higher MIC values found. Chlorhexidine is a chemical antiseptic, antifungal, and bactericidal capable of eliminating both gram-positive as gram-negative bacteria. Also it has bacteriostatic action, inhibiting bacterial proliferation by disrupting the cell membrane, and not by inactivating ATPase, as imagined before ${ }^{17}$.

It is rather difficult to compare our MIC values with other studies due to the particular features of the different bacterial strains and the reduction of the size of silver nanoparticles ${ }^{6,14,18}$. To assure consistency of the MIC value microdilution was performed in triplicate. However, systematic reviews indicate that chlorhexidine does not have enough scientific evidence to be used as a preventive agent for dental caries ${ }^{17}$. However, substances containing silver have been used in Dentistry, such as SDF, with high clinical efficacy ${ }^{13}$. Therefore, compounds 
containing silver nanoparticles have a great potential for dental caries prevention.

\section{Conclusion}

The AgNPs have bacteriostatic and bactericidal activity against $S$. mutans, which proves to be similar to chlorhexidine, and better than SDF. Thus, it is a promising new approach as a non invasive dental caries preventive agent.

\section{Acknowledgements}

We would like to thank Dr. Marcia Mayer (USP, Brazil), technician Leonardo Cruz (USP, Brazil), and the R. Niederman Forsythe Institute of Boston, USA. We would like to thank CAPES, The Brazilian Ministry of Education, CNPq, and the Brazilian Ministry of Science and Technology for financial support.

The authors report no conflicts of interest. The authors alone are responsible for the content and writing of the paper.

\section{Resumo}

Objetivo: para esclarecer os benefícios relacionados com o uso de nanopartículas de prata (AGNPS) na prevenção da cárie dental em crianças, foram comparadas as propriedades antimicrobianas de nanopartículas de prata, clorexidina e diamino fluoreto de prata (DFP) contra Streptococcus mutans. Materiais e método: para a análise da concentração inibitória mínima (MIC) foi utilizado o método de microdiluição por espectrofotometria (MME) e turbidez. Também foi observada a concentração bactericida mínima (CBM) desses produtos. Análise de variância (ANOVA) foi utilizada para comparar o MIC e o MBC entre os grupos estudados. Resultados: em relação às propriedades antimicrobianas, as substâncias testadas mostraram atividades bactericidas e bacteriostáticas eficazes. As nanopartículas de prata mostraram ter o menor valor de MIC frente às cepas de referência (ATCC 25175) ( $p<0,05)$. Nas estirpes clínicas, as nanopartículas de prata tiveram o valor de MIC análogo ao da clorexidina $(p>0,05)$ e foi inferior ao DFP $(p<0,05)$. Conclusão: nanopartículas de prata provaram ter atividade antimicrobiana contra $S$. mutans, portanto, podem ser um agente eficaz na prevenção de cáries dentárias.

Palavras-chave: Cárie dentária. Microbiologia. Streptococcus mutans.

\section{References}

1. Marmot M, Bell R. Social determinants and dental health. Adv Dent Res 2011; 23:201-6.

2. Loesche WJ. Role of Streptococcus mutans in human dental decay. Microbiol Rev 1986; 50:353-80.

3. Napimoga MH, Höfling JF, Klein MI, Kamiya RU, Gonçalves RB. Transmission, diversity and virulence factors of Streptococcus mutans genotypes. J Oral Sci 2005; 47:59-64.
4. Liu JL, Luo Z, Bashir S. A progressive approach on inactivation of bacteria using silver-titania nanoparticles. Biomater Sci 2013; 1:194-201.

5. Martinez-Gutierrez F, Thi EP, Silverman JM, Oliveira CC, Svensson $S L$, Hoek AV, et al. Antibacterial activity, inflammatory response, coagulation and cytotoxicity effects of silver nanoparticles. Nanomedicine. 2012; 8:328-36.

6. Hernandez-Sierra JF, Rui F, Pena DC, Martinez-Gutierrez F, Martinez AE, Guillen AJP, et al. The antimicrobial sensitivity of Streptococcus mutans to nanoparticles of silver, zinc oxide, and gold. Nanomedicine: Nanotechnology, Biology, and Medicine 2008; 4:237-40.

7. Qin Y, Ji X, Jing J, Liu H, Wu H, Yang WX. Size control over spherical silver nanoparticles by ascorbic acid reduction. Colloids and Surfaces A: Physicochemical and Engineering Aspects 2004; 372:172-6.

8. Lorian V. Antibiotics in laboratory medicine. Baltimore: Williams \& Wilkins; 1986

9. Cheng L, Weir MD, Zhang K, Xu SM, Chen Q, Zhou X, et al. Antibacterial Nanocomposite with calcium phosphate and quaternary ammonium. J Dent Res 2012; 91:460-6.

10. Weir MD, Chow LC, Chow LC, Xu HHK. Remineralization of demineralized enamel via calcium phosphate nanocomposite. J Dent Res 2012; 91:979-84.

11. Xu HHK, Weir MD, Sun L, Takagi S, Chow LC. Effects of calcium phosphate nanoparticles on Ca- $\mathrm{PO}_{4}$ composite. $J$ Dent Res 2007; 86:378-83.

12. Sheikh FA, Barakat NA, Kanjwal MA, Nirmala R, Lee JH, Kim H, et al. Electrospun titanium dioxide nanofibers containing hydroxyapatite and silver nano-particles as future implant materials. J Mater Sci Mater Med 2010; 21:2551-9.

13. Rosenblatt A, Stamford TCM, Niederman R. Silver diamine fluoride: a caries "silver-fluoride bullet". J Dent Res 2009; 88:116-25.

14. Espinosa-Cristobal LF, Martinez-Castanon A, Martinez-Maartinez RE, Loyola-Rodriguez JP. Antibacterial effect of silver nanoparticles against Streptococcus mutans. Materials Letters 2009; 63:2603-6.

15. Morones JR, Elechiguerra JL, Camacho A, Holt K, Kouri JB, Ramirez JT, et al. The bactericidal effect of silver nanoparticles. Nanotechnology 2005; 16:2346-53.

16. Baker C, Pradhan A, Pakstis L, Pochan DJ, Shah SI. Synthesis and antibacterial properties of silver nanoparticles. $\mathrm{J}$ Nanosci Nanotechnol 2005; 5:244-9.

17. Autio-Gold J. The role of chlorhexidine in caries prevention. Operative Dent 2008; 33:710-6.

18. Besinis A, De Peralta T, Handy RD. The antibacterial effects of silver, titanium dioxide and silica dioxide nanoparticles compared to the dental disinfectant chlorhexidine on Streptococcus mutans using a suite of bioassays. Nanotoxicol 2012; 15:1-16.

\section{Corresponding author:}

Valdeci Elias dos Santos Junior

Rua São Sebastião, 417/101

54410500 - Piedade Jaboatão dos Guararapes,

PE, Brazil

Telephone: 00558197446105

E-mail: valdeciodonto@gmail.com

Recebido: 15/10/2013. Aceito: 13/01/2014. 